\title{
MILITARIZATION OF INFORMATION IN CURRENT CONFLICTS
}

\author{
Richard STOJAR \\ University of Defence, Brno, Czech Republic \\ richard.stojar@unob.cz
}

\begin{abstract}
The information technologies used in the contemporary conflicts and the overall availability of social nets generate a number of usable information for their actors. This information environment breeds the chance of conducting the sophisticated and targeted operation of disinformation and effective impact on the actors involved as well as regional or global ones. While the information and propaganda dimension is not a completely new phenomenon, technological development has greatly strengthened its importance in the contemporary world. The development of modern media and communication tools in the 20th century have significantly influenced the very limited means of providing the information to society while the development of the Internet has made far more effective targeting of information on selected social groups than at any time in the past. The phenomenon of information warfare is therefore becoming increasingly frequent, and it is also possible to talk about the new character that conflicts gain through the information dimension. The paper tries to characterize and analyze the importance of the information environment in the current conflicts. Attention is focused on existing and new forms of propaganda, strategic communication and information operations on the social network.
\end{abstract}

\section{Keywords: information environment, propaganda, conflict, social network}

\section{Introduction}

Information and propaganda work is an integral part of the conflict, so it is not an element that would represent a fundamental change from the past. In the history, several significant waves of technological advances have taken place, which, on the one hand, have allowed the effective indoctrination of society and its mobilization in relation to conflict negotiations, while providing more detailed and qualitatively and quantitatively better awareness of ongoing conflicts than in the previous period.

Modern media has caused the war to be no longer a remote thing outside of the directly affected areas, which the civilian population only learned from brief announcements from the government or from the narratives of soldiers, often with a longer period of time after its end. Immediate contact between the scene of war operations and the home base given by the new communication possibilities gradually manifested itself even in the greater ambitions of the news media to cover often very remote areas.

Technical development was also reflected in the possibilities of more effective or at least more intense leadership of the propaganda by the parties to the conflict. However, the reach and impact on the armed forces or the adversary's society was still largely limited in the 20th century when it came to trying to influence its own or neutral society. If such cases occurred, they were linked to the internal instability of the hostile actor, and the propaganda itself was of very limited importance. 
However, the development of modern technologies has increased the potential of information and propaganda activity, whether on its own side or on the side of the adversary. At the same time, it has brought about a certain democratization, as current resources provide great opportunities to relatively weak power actors who have been marginalized in the sector a few years ago [1]. While we may agree with the view that information operations are often a very complex and costly process, the allocation of large resources is no longer an essential condition for effective action. Nevertheless, this opinion in the professional debate is still sometimes heard.

\section{Information operations and social networks}

The possibility of using the Internet and, in particular, social networks, compensates for the shortcomings that are and are particularly suited to non-state actors. These actors did not have adequate means of communication (mass media, radio and television broadcasts, daily newspapers, etc.) and were mostly dependent on improvisation, which in many cases could have been successful, but could not reach a larger audience. Now, even a small actor can address the whole global space with minimal means, spread his narrative of events, targeted misinformation, eventually to attack the information and propaganda of a powerfully and militarily superior adversary with far greater success than ever before [2].

Propaganda-like information can thus appear globally and in real time, with very limited counterparty options to prevent its spread. Virtually every conflict generates incidents that contradict war law and international conventions, regardless of the intentions of political or military leadership. The undesirable behaviour of actors at the level of individuals cannot be completely eliminated or eliminated in the psychologically challenging conditions of combat or stabilization operations. However, the documentation of major incidents or their consequences has never been easier, just like their media coverage in the information. Getting sympathy or empathy for your own goals, as well as demonizing or denigration of the enemy is technically much easier than in the past.

And even relatively non-serious manifestations of the unsuitable behavior of individual members of the armed forces can significantly hamper their own efforts in both combat and stabilization operations if they are documented and subsequently expanded. An example is the activity of a group of US troops deployed in Afghanistan who documented the defamation of Islamic belief by urinating on the Qur'an, which was, of course, contrary to the desire to win hearts and minds of the local population.

The interconnection of almost all the surface of the planet through an information network allows any actor almost immediate and unhindered access to vast amounts of data and their subsequent processing and use for their own needs. The information in this sense has gradually become a strategic raw material available both for building positions in this dimension and influencing the functioning of the real environment [3]. From the point of view of state and nonstate actors, ensuring stable access to this domain is effectively the primary prerequisite for effective pursuit of their own interests. In the event of an conflict, the ability to deny access to the adversary represents an important tool for achieving the set objectives [4].

The Internet and social media can be a very effective mobilization tool, capable of working across borders and geographical distances. At the same time, it brings unprecedented networking capability to followers and their further infiltration into a wider community or addressed company. Internet publishers can also guarantee their consumers a certain standard and authenticity (forums are accredited) and 
prevent access to material that is not ideologically reliable from the operator's point of view. Some actors may also use the notional mobilization of their sympathizers for information activities, or rent support services in selected areas.

The way in which information activities are realized today is often not only very difficult to suppress but also in some cases to be effectively monitored in terms of scale. In April 2014, when the northern Iraqi Mosul was conquered, the Islamic State (ISIS) led a tweet offensive in the information space in parallel, sending 40,000 messages a day. This quantity, combined with other applications, resulted that the user of Twitter was first confronted with images of ISIS fighters and the footage of occupied Mosul with the black ISIS flag and the inscription "Baghdad, we come!".

Later, the intensity of social networking activities increased, according to some data, the Islamic State had up to 25,000 registered Twitter accounts at the beginning of 2015, with an average of 200,000 messages per week [5]. Propaganda was an existential necessity for the survival of the Islamic State. And both for the physical power base itself and the active members, and for the very idea of extreme political Islamism [6].

It was an invaluable tool that provided support for this entity, while allowing a very geographically remote environment to penetrate and indoctrinate. By comparison, the propaganda activities of Iraqi insurgents operating only a decade earlier were much more modest.

While video recordings on various websites have already been of major importance, CD, DVD and especially recordings on cheap cassette tapes have also been used. On the contrary, the possibilities of effective information targeting given by social networks today were still absent.

The emphasis on the information activities of the Islamic state has also been reflected in a rather systematic approach to creating own propaganda and gaining new activists for this activity. In the spring of 2016 the Islamic State's official propaganda channel on social networking platform Telegram circulated a document entitled Media Operative, You Are a Mujahid, Too. This should have become a practical tool for media operatives to help them to streamline their activities.

Social networks with sophisticated algorithms can also effectively target with their information or misinformation specific social categories of recipients. While this usage is today mainly in the civil sector, commercial or political advertising, the possibility of using information for information in conflicts is identical. Thus, information and propaganda can affect selectively selected social groups with somewhat different content and make their activities more effective. For one group, they can rather use ideological and value arguments, for a second group material and social arguments. They may seek imaginative acquiring of the hearts and minds of a part of society, while at the same time intimidating the other segment of the society. In the past, information activities of a similar type were broadcasted via radio or TV without targeting and also leaflets could not target precisely and selectively in this way, and could in some cases be counterproductive.

Social networks, however, offer an unprecedented opportunity to obtain useful intelligence information beyond the possibilities of spreading propaganda and misinformation. It is currently an ideal tool for conducting information operations that is widely used [7].

Of course, social networks are not just a technological element but they reflect the whole-world trends that go across the civilian and military sectors [8]. It turns out that it is very difficult or almost impossible to prevent leaks of sensitive information through social networks. This phenomenon is confronted by the armed forces of practically all actors in many different conflicts. This trend does not make a 
distinction between regular or irregular armed forces, their internal structure, discipline or culture of their members. A mobile phone with the ability to record and connect to the Internet is a global tool without which many individuals, including those in the armed forces, can no longer imagine a common life. Fashion trends such as selfie making, and the insertion of different records into the social networks combined with human nature, lead to disregarding many strict regulations even by otherwise disciplined soldiers. Unwanted disclosure of the information by soldiers usable by the opponent becomes a common phenomenon.

The US Armed Forces had to address a number of incidents of this type, including in the conflict zones of Afghanistan or Iraq. For example, members of the US Armed Forces published social information about their current location, sensitive details about the bases on which they operated, event. information that could undesirably compromise their exposure to the eyes of the local population or the US public. A similar problem has also been encountered by Russian forces in operations in eastern Ukraine, which were in many ways highly classified and officially denied. Even here, Russian soldiers made pictorial records, in spite of bans, which they spread on social networks. This phenomenon, however, was typical of their Ukrainian opponents, who inadvertently provided the Russian side with a number of military useful information. Social network monitoring currently allows, for example, very effective tracking of the position and movement of units and military equipment.

In retrospect, the Bellingcat amateur investigative team was able to trace the movement of the Russian anti-aircraft system and its attendants, which is attributed to the shooting down of the Malaysia Airlines airplane over the proRussian separatists controlled territory of eastern Ukraine in 2014. One of the Russian responses to this development is the newly adopted law prohibiting members of the armed forces from sharing personal information on the Internet.

And the same problem with the failure to observe the minimum information security was also in the Islamic State. Even his warriors, despite the medieval mentality, often did not resist the spell of modern technology and the possibilities of selfpresentation in the virtual space.

\section{Conclusions}

Technological developments make it possible to lead propaganda and other information and psychological operations in a new quality in contemporary conflicts. The general availability of social media and mobile platforms with Internet access allows for a rapid dissemination of information even to the most isolated parts of the world or to address selectively selected social groups. Contrary to the past, today's global audience can be approached with relatively low costs, possibly by maintaining anonymity. While the information war was predominantly driven by state actors, it is currently open to nonstate actors, possibly even very small groups or even capable individuals. There can be no exaggeration to talk about a fundamental change in the possibilities to communicate or to think intent on the target group, a change comparable to the development of modern media and means of communication in the 20th Century. At the same time, however, this development also brings an unprecedented possibility of more effective targeting of information even to very specific and defined groups of addressees or, on the contrary, their effective monitoring and the possibility of obtaining previously difficult to obtain information. The information dimension is thus becoming increasingly important in contemporary conflicts. 


\section{Acknowledgements}

The work presented in this paper has been supported by the Ministry of Defence of the
Czech Republic (Research Project "STRATAL” No. 907930101023).

\section{References}

[1] Stojar, Richard, Vybrané trendy vývoje bezpečnostního prostředí a možné implikace pro ozbrojené síly, Brno, Univerzita obrany, 2017, p. 37.

[2] Stojar, Richard and Frank, Libor, Changes in Armed Forces and their Significance for the Regular Armed Forces, Proceedings of $18^{\text {th }}$ International Scientific Conference KBO, pp. 142-145, Sibiu, Romania, November, 2012.

[3] Fučík, Jakub, Revolution in Military Affairs and Outer Space, Proceedings of $23^{\text {th }}$ International Scientific Conference KBO, pp. 106-111, Sibiu, Romania, November, 2017.

[4] Majchút, Ivan, Deployability of Armed Forces in Irregular Warfare, Proceedings of $24^{\text {th }}$ International Scientific Conference KBO, pp. 133-134, Sibiu, Romania, November, 2018.

[5] Winter, Charlie, Media Jihad: The Islamic State's Doctrine for Information Warfare, London, Institute for Strategic Dialogue, 2017, pp. 1-27.

[6] Divišová, Vendula, Džihádistická propaganda v zemích Západu za účelem rekrutace, Rexter, Vol. 14, No. 2, pp. 1-28, 2016.

[7] Pavlíková, Miroslava and Hanzelka, Jan, Nástroje ruských aktivních opatření ve vybraných zemích EU, Political Sciences, Vol. 22, No. 1, pp. 108-131, 2019.

[8] Kosárová, Dominika, Information warfare and the contemporary security environment, Horyzonty bezpieczeństwa, Vol. 8, No. 3, pp. 17-33, 2017. 